\title{
Celebrated at first, then implied and finally denied: the erosion of Aboriginal identity in circus, $1851-1960$
}

\author{
Mark Valentine St Leon
}

Circus in a modern form was first presented in London in the late 18th century. Philip Astley (1742-1814), a former cavalryman, gave open-air displays of trick riding in 1768 in a ring within a roped-off field at Lambeth on the southern side of the Thames. These displays were eventually enclosed, roofed over and given in a building, which he called Astley's Amphitheatre. ${ }^{1}$ The establishment was popularly referred to as 'the circus', a word used at the time to describe the open-air circular recreational riding tracks in and around London. ${ }^{2}$ The ring, the essence of the circus experience, was a primordial device for grouping an audience around a spectacle of human activity. ${ }^{3}$ On the other side of the world, Australia's Aboriginal people employed the same device for ceremonies such as a corroboree, the earliest performances by Aborigines to be witnessed by Europeans. ${ }^{4}$ Astley's remained the international centre of circus well into the 19th century. By the early 1800s, provincial Britain was served by numerous circuses of various sizes and reputations, which travelled by road. ${ }^{5}$ These companies and others on the Continent, the newish United States and eventually in the new colonies of Australia mimicked Astley's programs. Also mimicked were the exquisite equestrian pantomimes devised by Andrew Ducrow (1798-1842), the principal equestrian, lessee and manager of Astley's from 1825 until his death.

Despite the popularity of circus entertainments in 19th-century England, circus performers inherited the inferior social standing of itinerant entertainers. They were not only placed towards the lower end of the English social hierarchy but also at the lower end of a hierarchy within the world of entertainers. ${ }^{6}$ These were people 'of no place and no order of life'. ${ }^{7}$ Similar observations could be made of some early Australian circus

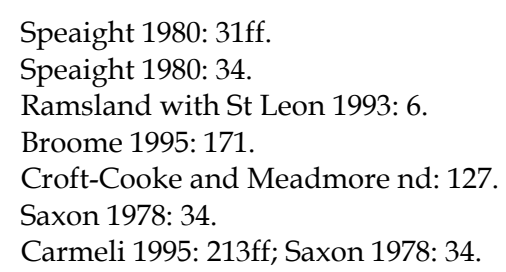


families as many were established by former convicts and other marginalised people such as former tinkers, chimney sweeps, bootmakers and hawkers.

\section{Circus blacks}

Many black performers were observed in British circus in the early 19th century and several were prominent as artists and managers. ${ }^{8}$ The international character of circus, then as now, placed more emphasis on physical skill than on identity while the public attached little importance to matters of race. ${ }^{9}$ The 'Negro' or mulatto rider (to use the language of the day), Joseph 'Mungo' Hillier, was a longstanding protégé of Ducrow. ${ }^{10}$ Another famous 'Negro' performer of this era was the equestrian, William Darby, better known by his nom d'arena of Pablo Fanque. ${ }^{11}$

Entertainments of a circus nature were among the manifestations of contemporary culture gradually transplanted to the new Australian colonies. A ropewalker named George Croft, a former convict, performed on the stage of Sydney's Theatre Royal as early as $1833 .{ }^{12}$ In April 1847, Croft opened a short-lived amphitheatre at Moreton Bay, the penal settlement where Brisbane now stands. ${ }^{13}$ In July 1841, Italian gymnast Signor Luigi Dalle Case arrived in Sydney unannounced with a small troupe that included two, presumably black or mulatta girls, aged 12 and 8, whom he had somehow procured from the Bahia region of Brazil. The girls exhibited feats of 'strength, tumbling and tightrope dancing. ${ }^{14}$ In Van Diemen's Land (now Tasmania) in December 1847, the publican and equestrian Robert Avis Radford opened his Royal Circus in Launceston and entertained audiences there and in Hobart Town over the following two years. ${ }^{15}$ There is no evidence that Radford presented any Indigenous people as performers at any stage, possibly because there was no 'exploitable native labour' in the colony. ${ }^{16}$

From 1850, the focus of colonial circus activity shifted to the mainland with fixed location 'amphitheatres' opened in both Sydney and Adelaide later that year and in Melbourne the following year. ${ }^{17}$ Black, but non-Aboriginal, performers were strongly represented in the 'Astley's Amphitheatre' that was opened in Melbourne late in 1854 by the entrepreneur GBW Lewis. Lewis's elephantine company, imported from London, included three ropewalkers, all 'men of colour'. ${ }^{18}$ They were Billy Banham, Harry Walker and George Christoff. The advertising for this Melbourne version of Astley's Amphitheatre touted Banham as the 'first rope dancer in the world' and that he could 'throw back and forward somersets, feet to feet, on the tight rope, a feat which astonishes those in the profession much more than those who pay to visit the arena'. ${ }^{19}$

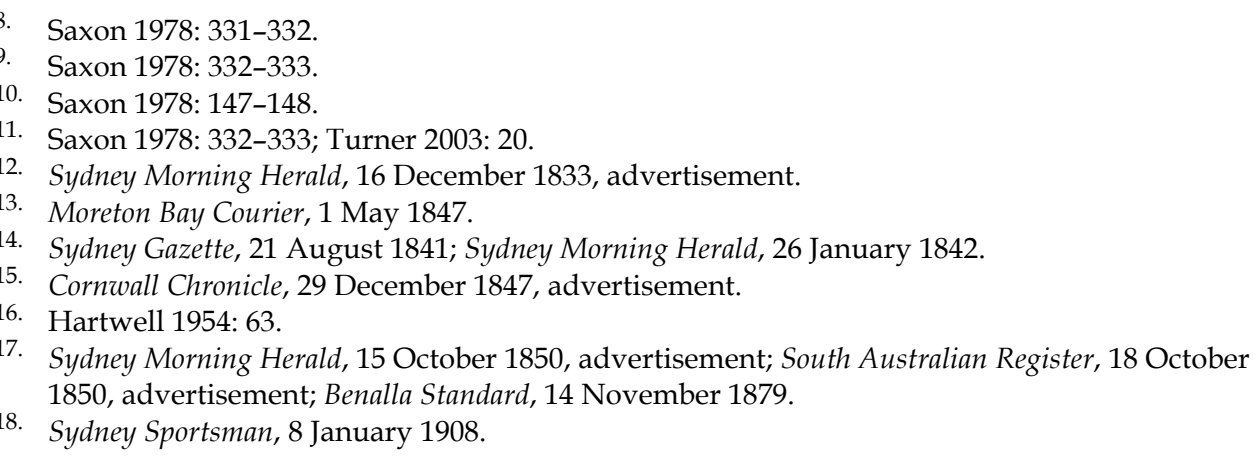


During this engagement and his subsequent ten-year sojourn in Australia, Banham deployed the nom d'arena of his famous uncle, Pablo Fanque. ${ }^{20}$

Despite the not infrequent arrival of performers from England, the United States of America and elsewhere by the 1850s - and performers moving from one troupe to another - the colonial circus proprietor was deprived of immediate access to the large pools of organised professional talent readily found in cities such as London, Paris or New York. Maintaining his company's strength and diversifying its program was therefore a constant challenge. In reviewing a performance of a visiting circus early in 1852, for example, a Goulburn, New South Wales, critic highlighted the need for 'two or three [more] performers [to] ... prevent ... delay between the parts and ... diversify the entertainments'. ${ }^{21}$

To satisfy the demands for both performers and novelty, circus proprietors sought attractive, suitably-proportioned juveniles to train as quickly as possible as acrobats or equestrians. As in England, an apprenticeship system was introduced in the early Australian amphitheatres to redress the colonial shortage of performers. ${ }^{22}$ The induction (or adoption) of children into 'apprenticeships' (however spurious) remained an established practice in Australian circus as late as the 1920s. Circus proprietors typically procured juveniles and youths from less-privileged backgrounds - typically, they were abandoned or illegitimate or both. ${ }^{23}$ As apprentices, young people were inexpensive, physically and mentally adaptable, controllable, welcomed by audiences and commercially exploitable over long periods. Of the known 'apprenticeships' of white children, few arrangements were contractually documented. As for non-white (mostly Indigenous) children, none of the known 'apprenticeships' was evidenced by contract (whether actual or anecdotal). ${ }^{24}$

\section{Identity celebrated, c1851-1865}

Novelty is the lifeblood of any entertainment form. However, the content of a program is determined as much by what can feasibly be delivered to an audience as by what public taste might demand. In this initial period of involvement in Australian circus, Aboriginal performers contributed to satisfying audience expectations of novelty. As a result, their presence in Australian circus was celebrated in this formative period, as Australian society was radically transformed from a penal past into a modern, commodity-based economy.

For want of an audience, the early circus troupes gradually abandoned the comfort of the amphitheatres to follow the people along ill-formed roads onto the gold diggings. ${ }^{25}$ As a result, the first peripatetic circuses were organised. The early travelling

19. The Age, 23 January 1855, advertisement. In the vernacular of the day, the term 'first' meant 'premiere' or 'outstanding'.

20. Turner 1995: 99.

21. Goulburn Herald, 3 January 1852.

22. Sydney Morning Herald, 30 November 1850, advertisement; New York Times, 17 February 1881.

23. King 1989, unpublished transcript of interview.

24. Broome 2001: 95.

25. Circus amphitheatres were in existence in various guises in Sydney (1850-56) and in Melbourne (1852-56). After short-lived initial success, they proved uneconomic and from 1853 (Sydney) and 1855 (Melbourne) the amphitheatres were gradually converted to theatres. 
circus proprietors also discovered a new source of children for 'adoption' or 'apprenticeship' - the so-called 'half-castes'. These children were the result of unions, voluntary or forced, between white men and Aboriginal women. ${ }^{26}$ A New South Wales Legislative Council Select Committee heard in 1845 that there was almost no inclination for white men to form permanent relations with their black concubines. ${ }^{27}$ Although commentary is by no means unequivocal, the overall picture obtained is that the 'halfcastes' at this time were the outcasts of both races. Among tribes in South Australia and Victoria, it was observed that 'half-castes' were destroyed at birth. In Western Australia in 1873 children and 'young persons of mixed blood' could be frequently seen 'utterly neglected and abandoned' and left to a life of 'ignorance ... vice and depravity' ${ }^{28}$

Early in 1851, in his circus erected outside a Parramatta inn, the English circus man, Henry Burton, presented an 'Indian' rider on his program. Since the presence of genuine Indian performers in Australian circus was rare indeed - two jugglers in 1862 the only ones to come to notice - we may conjecture that Burton's 'Indian' of 1851 was in fact an Aborigine and, if so, the first Aborigine to appear in colonial circus, indeed in any genre of the European performing arts. ${ }^{29}$ However, the identity of Burton's 'Indian' remains unknown: he may have metamorphosed into Burton's 'Little Nugget' a few months later, as detailed below, but we lack confirmation.

Why would Burton present a Aborigine as an 'Indian' and not as an 'Aborigine'? Would the presence of an Aborigine on his program detract from the image of his company? Possibly, since racist attitudes had grown by $1850 .{ }^{30}$ Was the term 'Indian' an acceptable contemporary descriptor for an Aborigine? Possibly, because some of the first settlers, conversant with the British colonial experience in North America, had described Australia's Aborigines as 'Indians' in their journals. ${ }^{31}$ Would the term 'Indian' better connect with Burton's colonial audience? Possibly, because for a time, the native-born of the colony of New South Wales were numerically stronger than the immigrants, free or otherwise, and we may speculate that a representative of 'the jewel' of the British Empire may have aroused more curiosity than an 'Aborigine', 'half-caste' or otherwise. ${ }^{32}$ In any case, how would a 'half-caste' be presented in a circus? In this era, half-castes were not the cause for remark that they would become within a generation or two. Ethnographic interest remained focused on Aborigines as relics of the Stone Age. If Burton's 'Indian' was the first Aborigine to appear in circus, he may have also been the first documented example of Aboriginal identity ambivalence, which, by the turn of the 19th century, bedevilled Australian society.

Burton reached the Turon River diggings with his circus troupe in July 1851, after trekking overland for several weeks from Maitland by way of Mudgee. ${ }^{33}$ He remained with his circus in the vicinity of Bathurst and Sofala for over a year. At Bathurst in August 1851, a juvenile 'half-caste' performer named 'Little Nugget', made his first

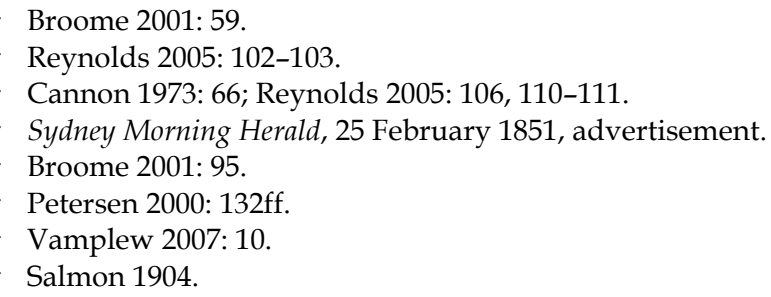


appearance with Burton's troupe. About seven years old, he was described as a 'manly little fellow of exquisite proportions', who leaped on and off his cream-coloured pony 'with pleasure in all directions; sometimes running by his side when at full speed, and vaulting with surprising nimbleness on his back'. ${ }^{34}$ The record shows that the boy was born near Dubbo about 1844, the son of a white labourer named William and an Aboriginal woman known only as Mary Ann. ${ }^{35}$ The following month, Burton's star performer, the equestrian, acrobat and ropewalker, John Jones, left to open his own circus at Sofala. ${ }^{36}$ Jones took several of Burton's performers with him including 'Little Nugget' who was given, or took, the name of his new mentor and was now known as 'Billy' Jones. Under other billings such as 'Master Parello Frank' and 'Master Pablo', as well as 'Little Nugget', the juvenile Billy's splendid performances became a feature of Jones' circus troupe in the following years. Billy's performances on the goldfields were still the cause of remark more than 40 years later when a columnist of the Sydney magazine, The Bulletin, reminisced:

[Jones'] circus tent consisted of side walls only and the lights were made of fish tins filled with mud and some fat and rags in the centre ... [Billy Jones] was 'carried' round by a rider standing up on a horse. The rider had tights, but Billy was dressed in trousers and shirt and was barefooted. The diggers of the Turon threw a large sum of money into the ring as a reward for his pluck. Later on, in Melbourne, $£ 1,000$ was offered [to John Jones] for the boy and pony by a speculator. [John Jones] replied: 'No, we have not got to slavery out here yet'. ${ }^{37}$

Due to floods in the Bathurst region, John Jones returned to Sydney in May 1852 to appear in Malcom's Amphitheatre in York Street with 'his talented company and stud of horses' as well as 'his two aboriginals', 'Master Parello Frank' [Billy Jones] and Master Bruce. ${ }^{38}$ They remained with Malcom nearly four months and the two boys were prominently featured, now unashamedly promoted to the Sydney public as 'Aboriginal'. ${ }^{39}$ In September 1852, Jones and his troupe, including the two Aboriginal boys, travelled overland to Melbourne to take up an engagement 'at the top of Bourke Street'

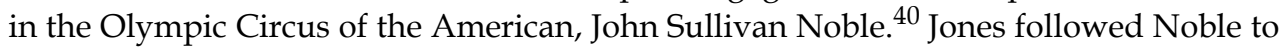
Geelong where they erected a circus of 'canvas and wood' in Ryrie Street. ${ }^{41}$ Billy continued to develop as a performer and, as Master Parello Frank, gave a 'benefit' performance in Geelong in February 1853, when he performed on horseback, jumped

Bathurst Free Press, 6 August 1851, advertisement.

35. New South Wales Registrar-General 1906, Death, William Jones, circus performer, no 7920; Sydney Morning Herald, 5 July 1906; Referee, 11 July 1906; New York Clipper, 15 September 1906. See also the Australian Dictionary of Biography for entry on Billy Jones.

36. Bathurst Free Press, 25 October 1851, advertisement. In 1865, Jones adopted the professional nom d'arena of 'St Leon'; he was my great-great-grandfather.

37. Bulletin, 9 March 1895.

38. Sydney Morning Herald, 19 May 1852, advertisement. The name 'Parello Frank' was an adaptation or editorial misspelling of 'Pablo Fanque', the professional pseudonym of the famous black British circus artist of the day, William Darby.

39. Sydney Morning Herald, 2 August 1852, advertisement.

40. Argus, 11 October 1852, advertisement.

41. Ovens \& Murray Advertiser, 22 December 1877; Geelong Advertiser, 1 December 1852, advertisement. 
through hoops, over garters and canvases, danced upon the tightrope and did a Sailor's Hornpipe, skills no doubt imparted to him by his mentor, John Jones. ${ }^{42}$

In Jones' Circus at Mudgee in 1858, Billy's dance on the tightrope was favorably compared to 'the celebrated Pablo Fanque, whom he bids fair to rival' ${ }^{43}$ Each afternoon before the evening's performance, Billy drew the attention of outback townspeople to Jones' circus by walking a rope, purportedly 300 feet in length and up to 70 feet above the ground, stretched from a tree stump to the centre pole of the tent. ${ }^{44}$

As other peripatetic circus troupes emerged during the gold-rush period to serve an increasingly diverse (and cosmopolitan and affluent) population, the novelty of presenting juvenile Aborigines as circus performers spread. In 1853 Ashton procured a young Aborigine from the Tamworth area. He gave the juvenile the name of Master Mongo Mongo probably after the British black performer 'Mungo' Hillier. Ashton trained Mongo Mongo to perform his 'many and daring feats on horseback' in under two years. ${ }^{45}$ Mongo Mongo was among a troupe of Aborigines that Ashton briefly presented when he visited the Hanging Rock diggings, near Uralla, in $1854 .{ }^{46}$ The following year, when Ashton took over the lease of Malcom's Amphitheatre, the performance of the 'Australian black' was depicted in the Illustrated Sydney News which described him as 'truly a wonder ... [who] reminds one of other lands from the beauty of his riding'. ${ }^{47}$ Mongo Mongo might have continued to enjoy colonial fame had it not been for his sudden death, apparently at the age of 20 from natural causes, while travelling the Illawarra with Ashton's troupe in $1856 .{ }^{48}$

'Ever willing to secure new performers at an apprentice's wages', and known to 'knock a back somersault out of a black in three lessons', Ashton regularly apprenticed juveniles as performers and 'turned out several good 'half-caste' performers' ${ }^{49}$ Alexander Alkanna, 'an Aboriginal boy from Moreton Bay', was one of Ashton's company in $1858 .^{50}$ From the 1850 s to the 1870 s, Ashton presented at least one or two Aboriginal (in most cases probably 'half-caste') performers on his program.

Ashton's Aboriginal 'apprentices' probably cost him little or nothing apart from board and keep and, in the absence of protective legislation, may have been readily procurable. In New South Wales for example, where Ashton concentrated most of his touring activity, the practices of 'baby-selling', adoption and trafficking in children,

\footnotetext{
Geelong Advertiser, 7 February 1853, advertisement.

Mudgee Liberal, 6, 13 July 1858.

44. Adelong Mining Journal, 16 October 1858, advertisement; Wagga Wagga Express, 9 July 1859, advertisement.

45. Goulburn Herald, 12 November 1853; Illustrated Sydney News, 6 May 1854, 23 June 1855; Bathurst Free Press, 13 January 1855. A 'Master Mungo' is also noted in JS Noble's Olympic Circus in Sydney in 1852, according to the Sydney Morning Herald, 10 June 1852, advertisement.

46. Illustrated Sydney News, 6 May 1854. The identity of the other members of the troupe is unknown.

47. Illustrated Sydney News, 23 June 1855.

48. Illawarra Mercury, 7 July 1856; New South Wales Registrar-General 1856, Death, Mongo, no 3234.

49. Wirth 1925: 9-10; Wirth 1933.

50. Ararat E Pleasant Creek Advertiser, 23 January 1858; Albury Border Post, 20 May 1858.
} 
Aboriginal or white, were not seriously addressed until the passage of the Child Welfare Act in 1923. The Destitute Children Act (New South Wales, 1866) and other similar child welfare legislation failed to protect Aboriginal and 'half-caste' children, ${ }^{51}$ nor did the legislation prevent the procurement of white children by circus proprietors. Of the several references uncovered to 'legally formalised' adoptions and apprenticeships of children by colonial circus proprietors, none pertain to Aboriginal or 'half-caste' children.

There was a pronounced decline in goldfield activity after $1854 .^{52}$ With the growing diversification of entertainment in the larger colonial capitals of Sydney and Melbourne and with the constant pressure to deliver novelty to their audiences, the permanent circus amphitheatres that opened in the early 1850s became viable once again, and all were transformed by 1856 into more conventional theatres. ${ }^{53}$ Rather than spelling the end of a colonial circus industry, these changes encouraged the industry to re-invent itself as fully peripatetic. We might even say 'nomadic', given the serendipitous manner in which the early circus routes developed as itinerant showmen explored their new territories. The itinerant circus proprietor was largely relieved of the burden of constantly delivering novelty in artistic programming. As the entertainers who travelled early modern Europe and the American frontier had already discovered, it was easier to change audience than repertoire. As a result, novelties - such as Aboriginal equestrians - enjoyed a longer life on the road than would have been the case in a fixed amphitheatre. ${ }^{54}$

Of whatever 'degree of mixture', Aboriginal performers initially enjoyed some status in this increasingly peripatetic Australian circus industry. Far from concealing their employment, circus proprietors such as Ashton, Jones and a few others actively celebrated their presence on their bills, if only one or two at a time. Why? A fundamental reason certainly lies in a continuation of the English circus custom of presenting a token black or mulatto performer on the program. A second reason lies in the upsurge in free immigration during and after the gold rush period, producing audiences for whom the sight of an Aborigine, even a 'half-caste', was an outright novelty (for a time at least). A third reason lies in the protective, paternalistic attitude of early circus proprietors towards the young Aborigines who redressed, to some extent, the chronic shortage of performers.

In the same era, larger numbers of Aborigines helped overcome severe labour shortages on country stations. ${ }^{55}$ In so doing, they shared for a time in the white man's recreations. Many, for example, became capable cricket players under the patronage of paternalistic station owners and managers. Aboriginal interest in cricket was sufficiently strong in the 1860s and 1870s to lead to the formation of Aboriginal cricket teams that played on the premiere colonial cricket grounds and even toured England. While many spectators undoubtedly came to see these players out of racial curiosity, the Aboriginal cricketers, like their counterparts in circus, garnered considerable

\footnotetext{
Thinee and Bradford 1998.

Cannon 1971: 210-211.

Irvin 1985: 173, 277-280; Argus, 14 April 1857, advertisement.

Burke 1994: 97.

Mulvaney and Harcourt 1988: 52.
} 
respect for their abilities. ${ }^{56}$ The employment of a small number of Aborigines in areas of sport (cricket) and entertainment (circus) by the 1860s was a foretaste of the limited career choices that Aborigines faced in the white man's world until well into the 20th century. ${ }^{57}$

In linking their fortunes to the circus, Aborigines were also unconsciously joining a 'class' of people who, in mother England, had been legally and socially classified for centuries as vagabonds and mountebanks. ${ }^{58}$ These classifications had no natural application in the new colonial context of circus, but the attitudes associated with them gradually surfaced with the first large waves of free immigration. Such attitudes were commonly articulated and fostered by the journalists and editors among the new arrivals. By the late 1860s, in some country towns 'hawkers' and 'travelling Jews with trinkets, organ-grinders, German bands, Ethiopian serenaders, circuses, electro-biologists, and people of that class', previously welcomed, were 'felt to be great nuisances' ${ }^{59}$ To counter such negative perceptions, circus proprietors went to some length to legitimise their reputations in the eyes of the emerging middle class by emphasising the good taste and refinement their entertainments offered. Visiting Adelaide in 1862, for example, circus proprietor Henry Burton assured 'parents and guardians' that his performances would be 'conducted with that due regard to propriety and delicacy that has hitherto characterised this establishment'. ${ }^{60}$

\section{Identity implied, c1865-1900}

While colonial circus proprietors continued to 'apprentice' and train Aboriginal (as well as white) children as performers, they also had to increasingly accommodate and reflect shifting middle-class values, as well as realising their own pretensions of respectability and legitimacy. Furthermore, by the late 1870s, there were growing calls for long-overdue innovation in programming. ${ }^{61}$ The unabashed presentation of Aborigines in circus - a polite novelty in the 1850s and the early 1860 s - began to fall out of step with emerging bourgeois sensibilities. The pinnacle of promoting performers as Aboriginal may have been reached in 1865 when, visiting Adelaide, Ashton presented his 'half-caste' performers, Master Callaghan and Combo Combo as 'The Aboriginal Brothers'. A thorough review of colonial circus advertising shows that thereafter the words 'Aboriginal', 'black' or 'half-caste' rarely appear in promotional material. ${ }^{62}$ Instead, oblique terms such as 'coloured' or 'Brazilian' were used to imply, rather than announce, the presence of Aborigines. ${ }^{63}$ The 1870s proved to be the last decade in which the presentation of Aborigines in colonial circus would be positively promoted. In this section, I will explore how colonial circus proprietors negotiated the emerging gap between audience expectations and what circuses could deliver.

\footnotetext{
Vamplew and Stoddart 1994: 69-70.

Cashmore 1982: 213-221.

Broome with Jackomos 1998: 47ff.

Cannon 1973: 247.

60. Advertiser, 4 January 1862, advertisement.

61. Australian Town \& Country Journal, 19 June 1875; Newcastle Morning Herald, 4 November 1878, advertisement.

62. Register, 27 March 1865, advertisement.

63. The News, 3 July 1875, advertisement; Clarence \& Richmond Examiner, 7 July 1874, advertisement.
} 
One of Ashton's 'Aboriginal Brothers' of 1865 was still travelling with Ashton as late as 1879 when he performed a 'back somersault over a nine-foot banner on a galloping horse' at Wilcannia. ${ }^{64}$ The other 'Aboriginal Brother', Combo, after several years with Ashton, travelled Victoria with Barlow's Circus in 1871 and toured Queensland with St Leon's Royal Victoria Circus in $1876 .{ }^{65}$ That Combo was able to move between these troupes suggests either that his freedom was unfettered or that the services of talented Aboriginal performers were actively traded between circus proprietors, possibly for consideration. ${ }^{66}$ Combo was long remembered as 'one of the best riders and acrobats' seen in the colonies. ${ }^{67} \mathrm{He}$ was 'taken' from 'the Gracemere run' (a large pastoral station outside Rockhampton) when 13 or 14 years old by Ashton. Did 'taken' mean 'stolen', 'adopted' or something else? We cannot say. Combo died in Brisbane in 1877 in 'rather straitened circumstances' at about 27 years of age. ${ }^{68}$

St Leon's presented another Aborigine on its program in 1876, Tony Hargreaves, better known as Master Antonio and later as 'Tony Tony'. St Leon's promoted neither Combo nor Antonio as 'Aboriginal', but Antonio was regularly billed as 'The Coloured Infant Prodigy'. ${ }^{69}$ Nevertheless, inside the tent, the Aboriginality of these performers was plain for all to see, as were their exceptional abilities as performers. A Rockhampton journalist patronisingly described Combo as 'a coloured gentleman', ${ }^{70}$ while to another observer he was 'a black boy of the darkest dye'. Antonio was capable of warping and weaving his body into extraordinary shapes and forms. ${ }^{71}$

A contemporary of Combo and Antonio was the young Aboriginal performer, Edward Campbell, presented by Ashton as 'Antonia, the Brazilian horseman' in Grafton in 1874. He performed one of Ducrow's most famous pieces of horsemanship, 'The English Fox Hunter', an act typically presented in traditional English riding costume. ${ }^{72}$ The contradiction of a swarthy 'Brazilian' performing in top hat and tails does not appear to have upset outback audiences. Campbell was fatally injured while performing in Ashton's Circus at Fernmount on the Bellinger River in $1881 .{ }^{73} \mathrm{~A}$ 'clever and deserving young man' who had been in Ashton's employment for a decade, Campbell's death cast 'a gloom over his comrades'. He was just 25 years old. ${ }^{74}$ After Edward Campbell's death in 1881, we do not read of an Aboriginal performer in Ashton's Cir-

64. Wilcannia Times, 24 July 1879.

65. Ovens \& Murray Advertiser, 1 August 1871, advertisement; Northern Argus, 25 April 1876, advertisement; Pattison 1939: 89.

66. According to the Illawarra Mercury, 7 July 1856, Ashton had earlier allowed Mongo to travel to the Peel River to visit his parents, after which Mongo voluntarily returned to Ashton's service.

67. Wirth 1925: 9-10; Wirth 1933; Ipswich Observer, 26 January 1876.

68. Daily Northern Argus, 10 October 1876; Uralla \& Walcha Times, 21 July 1877.

69. The News, 3 July 1875, advertisement. St Leon's 'Master Antonio' was, presumably, a different identity to Ashton's 'Master Antonia' of the same era.

70. Northern Argus, 1 May 1876.

71. Illawarra Mercury, 20 August 1875; Maryborough \& Dunolly Advertiser, 10 February 1879.

72. Clarence \& Richmond Examiner, 7 July 1874.

73. Frank Jones, letter filed in FitzGerald Papers, MS Q285, Mitchell Library, Sydney.

74. New South Wales Registrar-General 1881, Death, Edward Campbell, no 8354; Bulletin, 23 July 1881; NSW Government Gazette, vol 4: 5782. 
cus again until 1888 when a contortionist, placed well down on the bill, toured Queensland with the company.

The most popular circus performers, like the most popular circus companies, accumulated reputations over many years. The major Aboriginal identity in Australian circus in the latter half of the 19th century was unquestionably William 'Billy' Jones (c1844-1906), the 'Little Nugget' of Burton's Circus in 1851. He appeared with almost every Australian circus of note as equestrian, juggler, acrobat, rope-walker and ringmaster. Visiting Hobart with Foley's Californian Circus in 1866, Billy walked a rope stretched from the top of the circus pole to the Theatre Royal on the other side of Argyle Street, at a height of about 50 feet (15 metres) to the cheers of the people below. ${ }^{75}$ The performance left such an impression on spectators that he was readily recognised by many when he next visited Hobart in 1884 as ringmaster of St Leon's Circus. ${ }^{76}$ Such was his standing as a circus man that news of his death in Sydney in 1906 was reported as far away as New York. ${ }^{77}$ Billy Jones' obvious Aboriginality was neither promoted nor concealed by his various employers and was no barrier to his popularity among either the public or the profession. ${ }^{78}$

In the same era, as Cashman notes, segregated work practices were instituted on country stations. ${ }^{79}$ Apart from the ubiquitous Billy Jones, the major colonial circus company in the 1880s, St Leon's, did not carry any Aboriginal performers. The apparently reduced reliance on Aboriginal performers during the 1880s may also be explained by the expansion of protection, control and containment of Aboriginal people in New South Wales (the major touring area for most circuses) in this era: the creation in 1878 of the first Aboriginal reserves and missions; the appointment of a Protector of Aborigines in 1881; and the establishment, in 1883, of the Aborigines Protection Board, which would come to have increasing control over the lives of some 9,000 Aboriginal people in New South Wales. Anecdotally at least, it would appear that the few Aborigines inducted into circus life in the 1890s were procured in Queensland. It is also worth noting that, in this same era, the ranks of Australian circus performers were enriched and replenished with artists who arrived with the large American circuses and Japanese acrobatic troupes, but who chose to stay in Australia and join local companies.

Alick Orlandi was known in North Queensland by his native name, 'Reka'. Probably in 1893 or 1894, he 'left' his tribe and joined Gus St Leon's Palace Circus as it toured Queensland, just a few years ahead of the Aborigines Act (Queensland, 1897) which would have deprived him of any freedom of movement or association. ${ }^{80}$ At the time The Bulletin patronisingly observed that Aborigines were exhibiting 'an unhallowed desire to go into the show business wherever they could' ${ }^{81}$ By the time the Palace circus opened in Tamworth in February 1896, Orlandi was billed as the 'great African somersault turnover [who] throws double somersaults over 13 chairs clearing 25 feet' $^{\prime} .{ }^{82}$

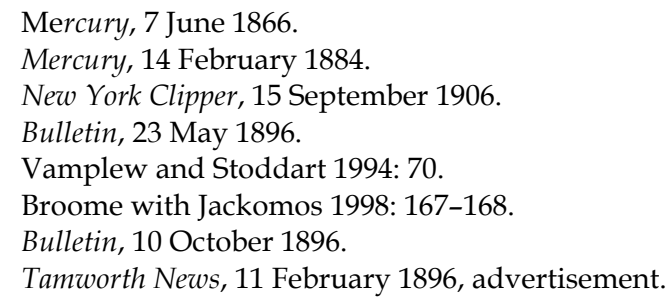


Orlandi 'possessed a magnificent physique' and executed the remarkable feat from a solid block of wood. At Greta a few months later, however, he slipped and landed head first on the ground with a sickening thud. ${ }^{83} \mathrm{He}$ died from his injuries soon afterwards. $^{84}$

Between 1886 and 1918, Aboriginal oppression increased as many reserves were broken up to satisfy settlers' demands for more land. By the turn of the century, most colonies had adopted legislation that deprived Aboriginal Australians of their freedom. Already deprived of the complexities of their own culture, Indigenous people were either confined to reserves or relegated to the fringes of country towns. In New South Wales in 1915, new legislation gave the Aborigines Protection Board the power to round up Aboriginal youths of mixed descent, especially girls, remove them from their parents and place them in apprenticeships or other forms of training. ${ }^{85}$ Aboriginality had become something to be 'denied, repressed, expelled and forgotten' ${ }^{86}$

\section{Identity denied, c1900-1960}

In this third period, Aborigines continued to play an important role in Australian circus. Aboriginality was neither overtly celebrated nor surreptitiously implied. It was instead denied - either voluntarily surrendered or actively repressed by unrelenting social and market imperatives. It is an era within living memory and so we can reconstruct to some extent the ways in which Aboriginal performers denied (or were denied) their identity. I turn now to consider the lives of the two most conspicuous Indigenous performers.

\section{Robert West (c1881-1943)}

Robert Benjamin Sooby (c1856-1949), the son of a London cab proprietor, landed in Australia in the 1860s as a 14-year-old. A liaison with a 'half-caste' Aboriginal woman named Charlotte Smith, led to the birth of a son, named Robert Sooby after his father, at Maitland in about $1881 .^{87}$ Although Sooby raised his Aboriginal son as his own, the boy was no longer welcomed when a white widow agreed to marry the elder Sooby. At Gunnedah, around 1891, Sooby 'apprenticed' his son to West Bros Circus conducted by an Englishman, Adam West. From the Wests, the young Bob learned everything about circus and became 'a fairly good rider' ${ }^{88}$ Just as Billy Jones had adopted his mentor's surname, so Bob adopted the name of West. ${ }^{89}$ Although light-skinned, his 'bit of dark blood' was obvious and, in the recollections of one old Australian circus man, he possessed 'a dash of the tarbrush' ${ }^{90}$ Bob West did not learn to read or write well. Visiting Narrabri with Foley's Circus in 1906, he was described as 'a most daring horseman' who 'delighted the audience' with his bareback riding. ${ }^{91}$ By November 1908, Bob West had taken to the road with his own circus, also called West Bros Circus. There is no ear-

\footnotetext{
Newcastle Morning Herald, 17 August 1896.

Armidale Chronicle, 26 August 1896.

Broome 2001: 87.

Broome with Jackomos 1998: 67ff; St Leon 1993: 37ff.

West, Philip, personal communication, 9 July 2002, Narooma.

St Leon 1984: 117.

9ill, Kitty West, personal communication 25 May 2008, Cairns.

90. King 1989, unpublished transcript of interview.
} 


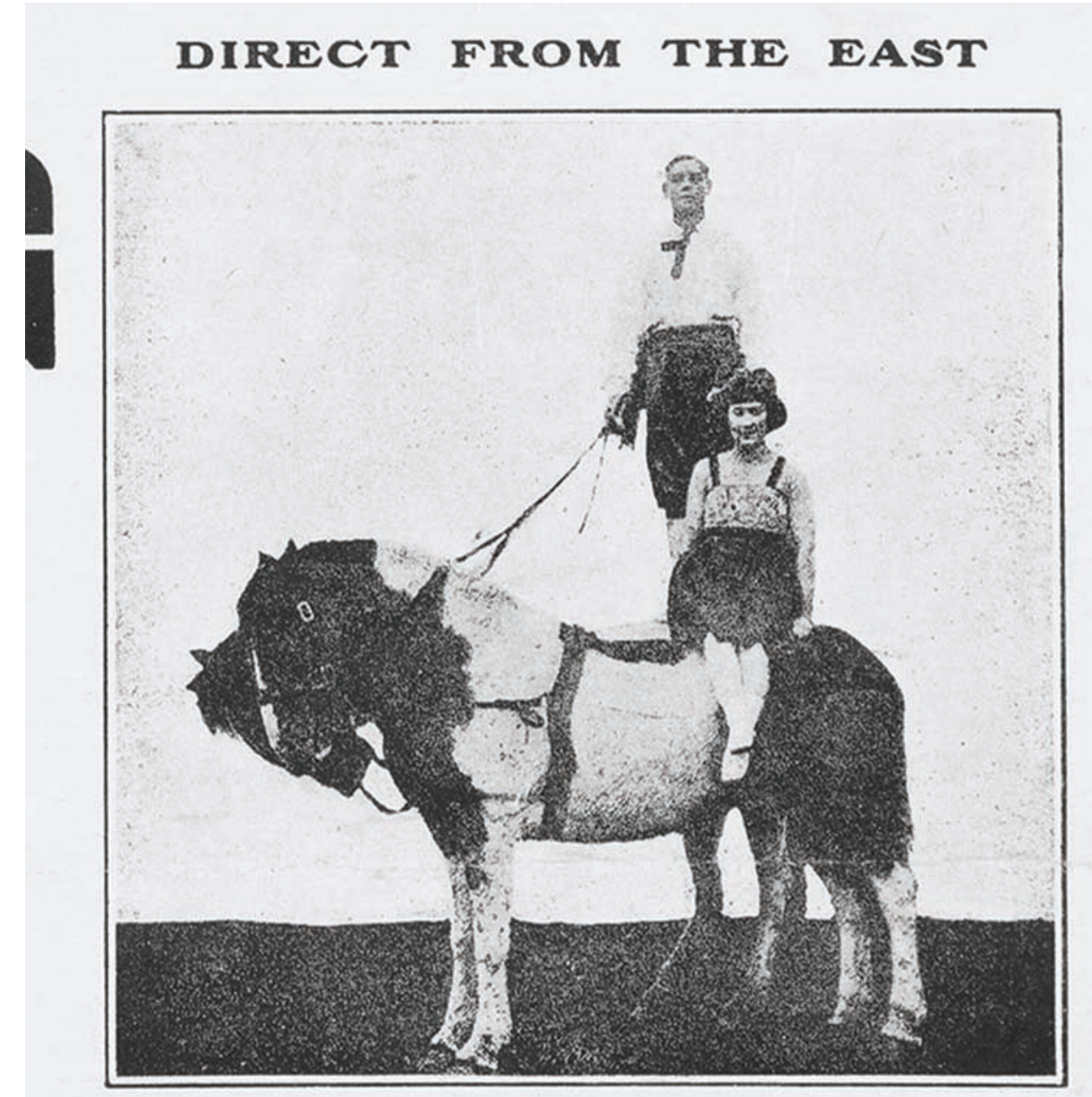

ROBT. WEST AND HIS DAINTY LADY PART NER

Robert West and his dainty lady partner, a Melbourne girl named Mary Davenport, who became the second Mrs West. This photograph dates from c.1919-20 and was reproduced on a poster for Sole Bros Circus in 1921. (Alexander Turnbull Library, Wellington, New Zealand.)

lier example known of a circus conducted by an Aboriginal person. At Wentworth that month, he claimed to have 'the largest circular tent in Australia ... brilliantly illuminated with gas jets'. 92

91. Narrabri Age, 20 July 1906. The Narrabri connection is at variance with the family recollection of a Maitland birthplace but may support the claim, as yet unverified, that West was actually a cousin of the Colleanos.

92. Federal Standard \& Western Districts Advocate, 25 November 1908. From Wentworth, the circus proceeded to Pooncarie, Menindee and Broken Hill. 
Something of a 'canvas casanova', Bob's first marriage in 1903 to Lucy O'Neill, a costume maker in FitzGerald Bros Circus, produced two daughters but the marriage ended in divorce in 1923. His second marriage to Mary Davenport, the daughter of a Melbourne bootmaker, at Wilcannia in 1928, produced nine children. ${ }^{93}$ In the summer of 1934-35, Bob and Mary West and their children were part of the last circus to travel across the Nullarbor Plain by wagons, with horses, donkeys and mules trailing behind. The crossing from Ceduna to Norseman took three and a half weeks. The family spent nearly four years travelling Western Australia before returning to South Australia by the overland route. The circus gave its last performance at Martin's Creek near Maitland, New South Wales, in May $1940 .^{94}$ The family settled at West Tamworth where Bob died in $1943 .{ }^{95}$ His younger children attended school 'as soon as we settled down' because a good education was 'the one thing Dad wanted us to have'. In keeping with the times, West appeared to 'resent' his Aboriginality and concealed his true ethnicity from his children, telling them they had 'Spanish blood'. Some of his younger children, none the wiser, only found out about the 'Aboriginal thing' from Bob's widow Mary shortly before she died in $1988 .^{96}$

\section{Cornelius 'Con' Colleano (1899-1973)}

Towards the end of the 19th century, Cornelius 'Con' Sullivan was a boxer and itinerant boxing troupe showman. At Narrabri in 1894, he married 16-year-old Julia Robertson, ${ }^{97}$ the daughter of William Robertson, a shearer and a native of the West Indies island of St Thomas (now one of the Virgin Islands) and Julia Robertson (nee Saunders), a 'half-caste' Aboriginal woman from

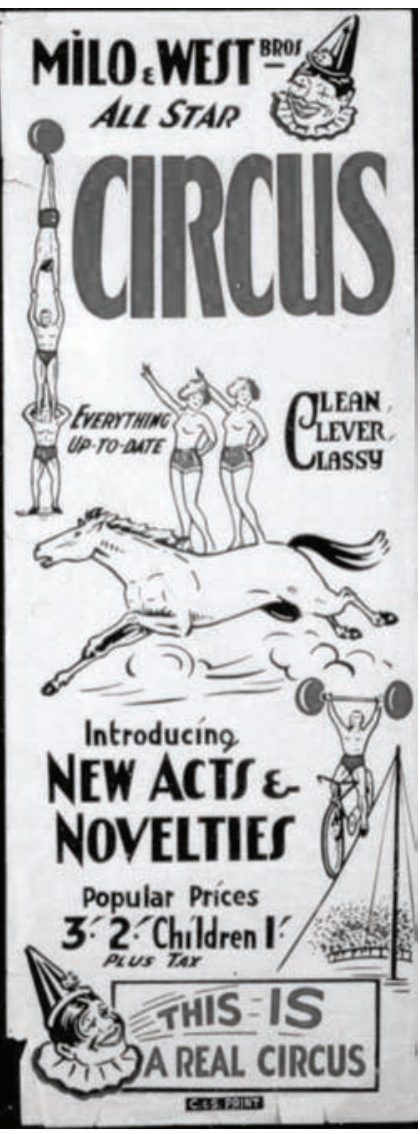

When touring Western Australia, Bob West combined his circus with another run by the Miller ('Milo') family for a few months about 1937. (Philip West, Narooma, NSW.) Wee Waa. ${ }^{98}$ In time, ten children followed: four boys and six girls. At Lismore in December 1899 the Sullivans'

93. New South Wales Registrar-General 1903, Marriage, Robert West Sooby and Lucinda O'Neil, no 564 .

94. North Shore Times, 4 March 1987; West, Philip, personal communication, 21 June 2008, Narooma.

95. New South Wales Registrar-General 1943, Death, Robert West Sooby, no 13400.

96. West, Philip, personal communication, 21 June 2008; Mervyn King, in St Leon, 1984: 265.

97. New South Wales Registrar-General 1878, Birth, Julia Robinson, no 17526; 1894, Marriage, Cornelius Sullivan and Julia Robinson, no 5188. Julia's name was later recorded as Vittorine Julia Robinson.

98. The presence of a West Indian in the Australian backblocks intrigues. It may be that Robertson was a sailor who jumped ship in Australia and made his way into the obscurity of the outback. 
third child was born, known, like his father, as 'Con' .99 Between 1907 and 1910, the family settled at Lightning Ridge, where the growing children received some schooling and learnt basic circus skills. The children 'didn't have a marvellous education but they could all read and write and add up' ${ }^{100}$ A preponderance of daughters probably put an end to any plan that Con Sullivan may have had to continue in boxing and so he turned instead to circus. Late in 1910, the family started touring northern New South Wales with its own circus, ${ }^{101}$ using the professional name of 'Collino' (later spelt 'Colleano'). The name was possibly inspired by an American troupe of acrobats, The Kellino Family, who visited Australia in 1897. ${ }^{102}$ This Latin sounding name capitalised on and conveniently camouflaged the swarthy appearance of the Sullivan children.

By late 1912, the young Con Colleano, then 13, and an older brother were accomplished acrobats and ropewalkers. ${ }^{103}$ The Colleano family further honed their circus skills by joining established circus companies such as Ashton's (1913) and Eroni Bros' (conducted by the Perry family) in 1914-15. When the Colleano boys were not performing in the circus ring, they boxed in their father's sideshow after the show each night. Interviewed in 1987, George Perry (c1896-c1989) recalled how 'young Con' was billed as 'The Boy Wonder' taking on all-comers up to 15 years of age. ${ }^{104}$

Sufficiently endowed with circus skills and experience, the Colleanos organised their own circus and started out once again, from Winton with 'just a few wagons and horses', probably in the spring of $1915 .{ }^{105}$ Members of the Matthews family (Aboriginal cousins of the Colleanos) also took roles in the circus. Family members filled multiple roles in the ring performance to minimise the need for employed artists. To create the impression of a much larger troupe and one that was imported, family members assumed a number of pseudonyms: the siblings Bonar, Winnie, Con, Kate and Maurice Colleano performed as acrobats billed as 'The Royal Hawaiians'; Winnie Colleano was the trapeze artist, 'Senorita Sanchez'; Con Colleano was the wirewalker, 'Zeneto'; Winnie and Kate Colleano were the double trapeze act, 'The Marasetta Sisters'; and Kate Colleano was the rider, 'Miss Katherine'. ${ }^{106}$ None of these names conveyed anything 'Aboriginal', and the illusion created of a circus replete with foreign exotica addressed to some extent the Australian public's insatiable demand for imported artists. Only a few years earlier, the Sydney magazine, The Theatre, had lamented the tendency of Australian audiences to pay 'outsiders [non-Australians] more for giving them less' as well as theatrical managers who grovelled 'to cater to these un-Australian Australians' instead of developing domestic talent. ${ }^{107}$ The billing of 'The Royal Hawaiians', consistently used in the Colleano advertising in the approximate period 1916-20, was borrowed from a troupe of genuine Hawaiian singers and dancers, which visited Australia in $1911 .{ }^{108}$

99. New South Wales Registrar-General 1900, Birth, Cornelius Sullivan, no 4386.

100. Trevail 1987, unpublished transcript of interview.

101. Warialda Standard, 28 November 1910, advertisement.

102. Sydney Morning Herald, 24 December 1897, advertisement.

103. Hillston Spectator, 14 December 1912.

104. Perry 1987, unpublished transcript of interview.

105. St Leon 1984: 100.

106. The Western Star, 10 February 1917, advertisement.

107. The Theatre, 1 February 1909. 
The appearance of Aboriginal girls in Colleano's All-Star Circus (as it soon became known) was itself striking. Of the Aborigines and half-castes known to have performed in Australian circus up until this time, none was female. The written and spoken record neglects to tell us why circus proprietors failed to 'apprentice' or 'adopt' Aboriginal girls or young Aboriginal women. Suitably proportioned females (whatever their ethnicity) were in such short supply in Australian circus that the more slender young male performers often dressed in drag to impersonate equestriennes and trapeziennes. ${ }^{109}$ While protective reserve managers and missionaries probably dissuaded girls from joining these morally dangerous institutions and saved them for lives of domestic service, such measures would not explain the fate of abandoned 'halfcaste' girls found beyond the reserves and missions.

Country newspapers, as well as the show business magazines of the era (such as The Theatre, Australian Variety, and The Hawklet) were consistent in their praise of the Colleano circus and its program. Country people could not fail to be impressed by any circus which (from 1918) was conveyed by rail, carried a band of 14 musicians and its own electric lighting plant. ${ }^{110}$ If Australian journalists knew of or perceived the family's Aboriginal origins - and it is hard to imagine that they did not - they were silent on the matter. Within Australia's circus community, on the other hand, the family was highly regarded

108. Sydney Morning Herald, 3 April 1911, adv

109. Pattison 1939: 91.

110. Western Star, 10 February 1917; Australian Variety, 11 October 1918.

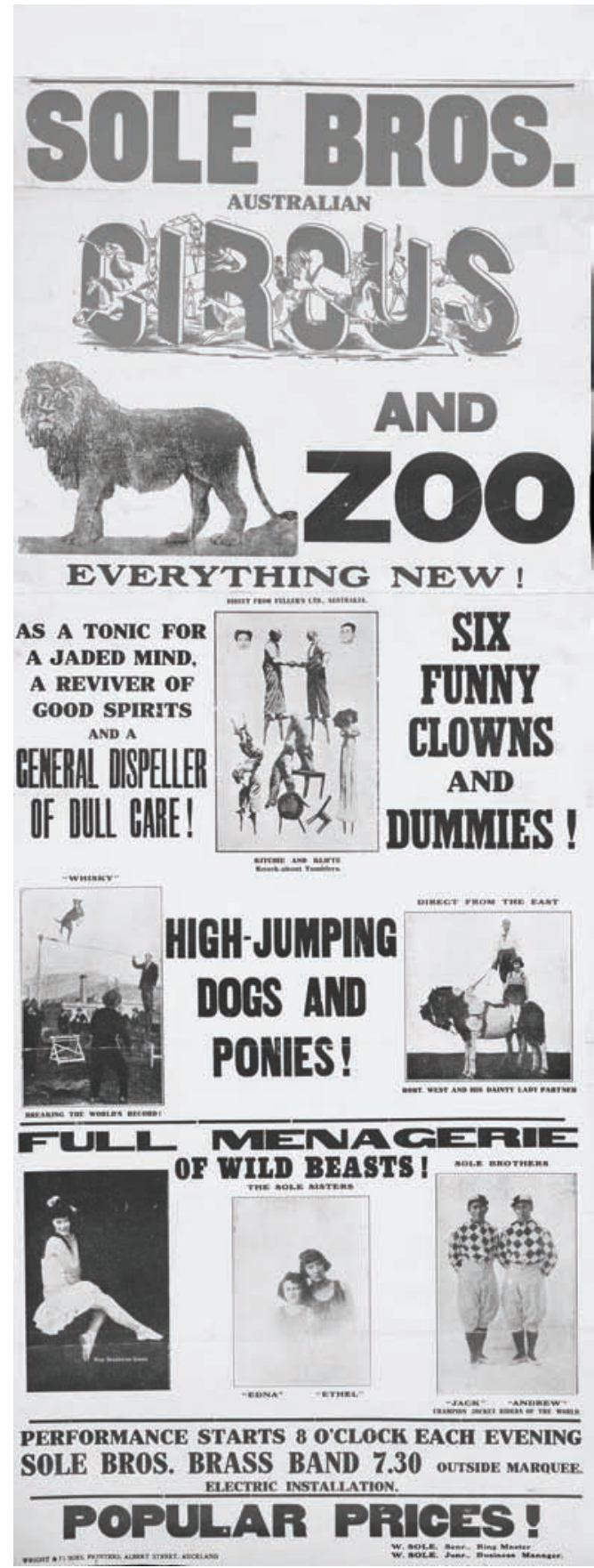

Poster for Sole Bros Circus used on its first New Zealand tour of 1921. (Alexander Turnbull Library, Wellington, New Zealand.) 
but unequivocally remembered as 'Aboriginal'. As George Perry said, 'They was all good people ... but people didn't treat them as Aborigines'. ${ }^{111}$

The feet-to-feet forward somersault on a tightwire is one of the most difficult and dangerous feats in circus performance because, as he tucks his head and turns his forward somersault, the performer loses sight of the wire and his feet have to find it. The perfection of this supreme feat took Con Colleano about five years of experimentation. At practice in Sydney in 1919, Con brought off his first forward somersault, possibly the first time the feat had ever been achieved on a wire (as distinct from a rope) and probably the first time by anyone since the renowned Billy Banham. ${ }^{112}$ It would still be some years before he could sufficiently refine the trick for public exhibition. In the meantime his back somersaults on the wire were sufficiently thrilling: the South Australian governor and his wife rose from their seats after Con's performance one Friday evening in Adelaide in 1921 and rushed into the ring to 'personally congratulate' him after his vice-regal performance. ${ }^{113}$

Rising rail costs forced the closure of Colleano's All-Star Circus early in 1923. The Fuller vaudeville circuit and later the rival Tivoli circuit soon engaged the family. ${ }^{114}$ Each circuit comprised vaudeville theatres in the major cities of Australia and New Zealand. As contemporary publicity shows, neither circuit actively promoted the Colleano family's Aboriginality. Indeed, the Tivoli management presented the eight acrobats of the family in Arabian costume, an implied imported act, The Akabah Arabs. ${ }^{115}$ On his own, Con Colleano was paid the extraordinary salary of $£ 60$ a week for his tightwire performance - in an era when the most capable Australian circus performers received only $£ 5$ a week. ${ }^{116}$ The Theatre described Con Colleano's act at Fuller's Sydney theatre in May 1923:

Colleano's dancing on the slackwire at Fuller's Theatre is the prettiest thing to watch. His small feet twinkle gracefully in pirouette and entrechat alighting always on the wire with an effortless sureness that disguises the difficulty of the act ... Colleano's dressing is admirable. His slim figure and almost Italian [sic] darkness of face and hair are fittingly set off by the white satin suit ... His forward somersault is his star act. ${ }^{117}$

Late in 1923, the Colleano family left Australia for vaudeville engagements in South Africa, England and the United States. In September 1924, Con Colleano made his successful American debut at the New York Hippodrome. ${ }^{118}$ With a nod to the silent screen hit of Blood and Sand and its swarthy bullfighter hero, Rudolf Valentino, Colleano had by then incorporated the pseudo-Spanish bullfighting ambience that remained the trade mark of his act for the remainder of his career. In 1925, Con secured an engagement with America's largest circuses, Ringling Bros and Barnum \& Bailey. While at first promoted to the American public as 'the Australian wizard of the wire',

\footnotetext{
111. Perry 1987, unpublished transcript of interview

112. Daily Mirror, 3 September 1919.

113. Everyone's, 4 January 1922.

114. Everyone's, 14, 21 March 1923.

115. Theatre, 2 April 1923.

116. St Leon 1984: 205.

117. The Theatre, 1 May 1923.

118. Variety, 1 October 1924.
} 
the novelty value of 'Australian' was soon fully depreciated. By the early 1930s, he was heralded in the Ringling publicity as a 'caballero ... from a famous Spanish family of circus performers', and his Aboriginal mother was transformed into 'a Spanish dancer whose parents had come from Las Palmas' ${ }^{119}$ With Ringling in 1933, Con drew a weekly salary of US\$375 - about $£ 150$ - and other benefits, such as his own apartment on the circus train, well in excess of any other performer in the circus. ${ }^{120}$ Touring Europe during the winter off-seasons, Colleano performed before enthusiastic audiences in Germany in December 1934, Adolf Hitler among them, as the 'Mexican tightwire wonder' ${ }^{121}$

As the lucrative American and European circus, vaudeville and fair circuits kept Con and other members of the Colleano family in regular employment throughout the 1920s and 1930s, news of their activities gradually vanished from Australian show business columns. When Con Colleano gave the final performance of his career in Honolulu in 1960 and died in Miami, in 1973, neither milestone came to the attention of the Australian press.

While Con Colleano never privately referred to himself as a Spaniard, he never publicly referred to himself as an Aborigine, although he was certainly aware of the fact. The misinformation permitted Con to enjoy privileges that otherwise might have been denied him. For example, he was issued a Reichspass allowing him to freely enter and depart Nazi Germany. ${ }^{122}$ He was able to assume American citizenship in 1950 (describing himself as 'white' on the citizenship document), although full citizenship rights were not extended to Aborigines at home until the passage of reforming federal and state legislation in the $1960 \mathrm{~s} .{ }^{123}$ During a failed attempt to retire to Australia in 1956-57, Con Colleano briefly held a publican's licence for a hotel at Forbes, although the sale of alcohol to Aborigines in New South Wales was not legalised until 1963. ${ }^{124}$

\section{Conclusion}

While Aboriginal performers made a valuable contribution to Australian circus, they were not represented in large numbers before the emergence of the Colleano and West families and their subsequent progeny. There were as many as 3,000 circus performers active in Australia over the period 1851-1960 and at least several hundred active at any one time by the first decade of the 20th century. The proportion of Aboriginal performers amongst them was by no means large - perhaps between 2 and 5 per cent of all active performers throughout Australia at any one time, but roughly consistent with the proportion of Aborigines in the total population. ${ }^{125}$

In circus, Aboriginal people found an accommodation with Europeans that could not be found elsewhere: equality, security and esteem, and a medium through which they could meaningfully engage with white society. But unwittingly, Aboriginal circus

119. Kelley 1931.

120. Ringling Bros and Barnum \& Bailey, Payroll manifest, 1933.

121. Scala Theater, Berlin, program, December 1934: 10-11, 20; St Leon 1984: 213.

122. Pix, 29 January 1938.

123. Broome 2001: 182.

124. Forbes Advocate, 6 July 1956.

125. Vamplew 2007: 4. 
performers had joined the company of people who were also marginalised and who for centuries were ranked at the lower end of the social scale. To maintain its social acceptability, circus had to constantly re-align itself with evolving social standards and expectations. If emerging Australian society marked down whatever respect and appreciation it may have once had for Aboriginal identity, then circus had to reflect the signals imparted. Thus, while the transition was by no means smooth, the prized figure of Burton's 'Little Nugget' of 1851 - the barefooted and obviously Aboriginal outback urchin - had metamorphosed by the 1920s into the cosmopolitan 'Wizard of the Wire' whose Aboriginality was camouflaged by a contrived Spanish heritage that satisfied the imperatives of Australian and, later, international show business.

\section{References}

\section{Primary sources}

FitzGerald Papers, MS Q285, Mitchell Library, Sydney.

Gill, Kitty West, personal communication 25 May 2008, Cairns.

King, Mervyn, 1989, unpublished transcript of interview, tape 35 [Author's collection]. Perry, George ['Eroni'] 1987, unpublished transcript of interview [Author's collection]. Ringling Bros and Barnum \& Bailey 1933, Payroll manifest [Author's collection]. Scala Theater, 1934, program, Berlin (December) [Author's collection].

Trevail, Eric 1987, unpublished transcript of interview [Author's collection].

West, Philip, personal communication, 9 July 2002 and 21 June 2008, Narooma.

\section{Secondary sources}

Broome, Richard 1995, 'Enduring moments of Aboriginal dominance: Aboriginal performers, boxers and runners', Labour History 69: 171-187.

-2001, Aboriginal Australian: Black Responses to White Dominance, Allen \& Unwin, Sydney.

— with Jackomos, Alick 1998, Sideshow Alley, Allen \& Unwin, Sydney.

Burke, Peter 1994, Popular Culture in Early Modern Europe, Ashgate Publishing, Aldershot.

Cannon, Michael 1971, Who's Master? Who's Man? Australia in the Victorian Age, vol 1, Currey O'Neil, Melbourne.

- 1973, Life in the Country: Australia in the Victorian Age, vol 2, Thomas Nelson, Melbourne.

Carmeli, YS 1995, 'The invention of circus and bourgeois hegemony: a glance at British circus books', Journal of Popular Culture 29(1): 213-221.

Cashmore, Ellis 1982, Black Sportsmen, Routledge and Kegan Paul, London.

Croft-Cooke, Rupert and WS Meadmore nd, The Sawdust Ring, Odhams Press, London.

Hartwell, RM 1954, The Economic Development of Van Diemen's Land, 1820-1850, Melbourne University Press, Melbourne.

Irvin, Eric 1985, Dictionary of the Australian Theatre, 1788-1914, Hale \& Iremonger, Sydney. 
Kelley, Frances Beverley 1931, 'The land of spangles and sawdust', National Geographic $60(4)$.

Mulvaney, John and Rex Harcourt 1988, Cricket Walkabout, Macmillan, Melbourne.

Pattison, JG 1939, 'Battler' Tales of Early Rockhampton, Fraser \& Jenkinson, Melbourne.

Petersen, RC 2000, 'Instructing the Indians at Botany Bay', Aboriginal History 24: 132-140.

Ramsland, John (with St Leon Mark) 1993, Children of the Circus: The Australian Experience, Butterfly Books, Springwood.

Reynolds, Henry 2005, Nowhere People, Penguin Books, Sydney.

Salmon, Mary 1904, 'An old-time circus', Australian Town \& Country Journal, (3 August).

Saxon, Arthur H 1978, The Life and Art of Andrew Ducrow and the Romantic Age of the English Circus, Archon Books, Hamden, Connecticut.

Speaight, George 1980, A History of the Circus, Tantivy Press, London.

St Leon, Mark 1984, Australian Circus Reminiscences, self-published, Sydney.

- 1993, The Wizard of the Wire: The Story of Con Colleano, Aboriginal Studies Press, Canberra.

- 2005, Circus in Australia, vol 2: Index of Show Movements, 1833-1969, self-published, Sydney.

Thinee, K and T Bradford 1998, Connecting Kin: A Guide to Help People Separated from their Family Search for Their Records, Department of Community Services, Sydney.

Turner, John M 1995, Victorian Arena: The Performers. A Dictionary of British Circus Biography, vol 1, Lingdales Press, Liverpool.

- 2003, 'Pablo Fanque, black circus proprietor', in G Holbrook Gerzina (ed), Black Victorians, Black Victoriana, Rutgers University Press, New Brunswick.

Vamplew, Wray 2007, Australians: Historical Statistics, Fairfax, Syme \& Weldon Associates, Sydney.

— and Brian Stoddart 1994, Sport in Australia: A Social History, Cambridge University Press, Melbourne.

Wirth, George 1925, Round the World with a Circus: Memories of Trials, Triumphs and Tribulations, Troedel \& Cooper, Melbourne.

— 1933, 'Under the big top: the life story of George Wirth, circus proprietor', Life, (15 June). 